\title{
Evaluation of Care for At-Risk Newborns from the Perspective of a Public Health Policy ${ }^{1}$
}

\author{
Ana Lúcia Forti Luque ${ }^{2}$ \\ Célia Mara Garcia de Lima ${ }^{3}$ \\ Maria Antonieta de Barros Leite Carvalhaes ${ }^{4}$ \\ Vera Lúcia Pamplona Tonete ${ }^{5}$ \\ Cristina Maria Garcia de Lima Parada ${ }^{6}$
}

\begin{abstract}
The aim was to evaluate the care for at-risk newborns under follow-up in their first year of life by the Growing Happily Program, developed in a city in inner São Paulo state. It is a population-based epidemiological health program evaluation study, which was based on the national guidelines of the Agenda of Commitments to Children and Child Mortality Reduction for data analysis. Results showed the program's institutional vulnerability, caused by problems related to its structure and process, with implications for its outcomes. Considering the adaptation of the criteria adopted by the Program for defining at-risk newborns, as well as the proposed interventions and strategies, in consonance with the Agenda of Commitments, the need for managers to make it a priority is appointed, by effectively including it in public health care policies to be developed in cities, in order to reverse the institutional vulnerability identified.
\end{abstract}

Descriptors: Health Services Evaluation; Risk Groups; Infant, Newborn; Vulnerability.

Paper extracted from Master's Thesis "Avaliação da atenção prestada ao recém-nascido de risco no município de Botucatu-SP", presented to Programa de Pós-graduação em Enfermagem, Faculdade de Medicina, Universidade Estadual Pauslita "Júlio de Mesquita Filho", Botucatu, SP, Brazil. This research was supported by Secretaria de Estado da Saúde de São Paulo.

${ }^{2}$ RN. E-mail: luque@btu.flash.tv.br.

${ }^{3}$ Dentist, Ph.D. in Nursing. Prefeitura Municipal de Ribeirão Preto, SP, Brazil. E-mail: lima@eerp.usp.br.

${ }^{4}$ Nutritionist, Ph.D. in Nutrition, Professor, Faculdade de Medicina, Universidade Estadual Pauslita "Júlio de Mesquita Filho", Botucatu, SP, Brazil. E-mail: carvalha@fmb.unesp.br.

${ }^{5}$ RN, Ph.D. in Nursing, Professor, Faculdade de Medicina, Universidade Estadual Pauslita "Júlio de Mesquita Filho", Botucatu, SP, Brazil. E-mail: vtonete@uol.com.br.

${ }^{6}$ RN, Ph.D. in Nursing, Adjunct Professor, Faculdade de Medicina, Universidade Estadual Pauslita "Júlio de Mesquita Filho", Botucatu, SP, Brazil. E-mail: cparada@fmb.unesp.br.

Corresponding Author:

Célia Mara Garcia de Lima

Rua: Primo Tronco, 129, Ap. 34

Bairro: Vila Virgínia

CEP: 14030-020 Ribeirão Preto, SP, Brasil

E-mail: lima@eerp.usp.br 


\section{Avaliação da atenção ao recém-nascido de risco, na perspectiva de uma política pública de saúde}

Objetivou-se avaliar a atenção à saúde de recém-nascidos de risco, acompanhados no primeiro ano de vida pelo Programa Crescer Feliz, desenvolvido em município do interior paulista. Trata-se de estudo epidemiológico populacional, do tipo avaliação de programa de saúde, que se baseou, para análise dos dados, nas diretrizes nacionais da Agenda de Compromissos da Criança. Os resultados evidenciaram a vulnerabilidade institucional do programa, decorrente de problemas relacionados à estrutura e processo, com implicações nos resultados. Considerando a adequação dos critérios adotados pelo programa, para definição dos recém-nascidos de risco e das intervenções e estratégias propostas, que se mostram em consonância com a Agenda de Compromissos, apontase a necessidade dos gestores priorizá-lo, inserindo-o, efetivamente, na política pública de saúde a ser desenvolvida no âmbito do município, para reversão da vulnerabilidade institucional identificada.

Descritores: Avaliação de Serviços de Saúde; Grupos de Risco; Recém-Nascido; Vulnerabilidade.

\section{Evaluación de la atención al recién nacido con riesgo bajo la perspectiva de una política pública de salud}

Se objetivó evaluar la atención a la salud de recién nacidos con riesgo acompañados en el primer año de vida por el Programa Crecer Feliz, desarrollado en un municipio del interior del estado de Sao Paulo. Se trata de un estudio epidemiológico poblacional del tipo evaluación de programa de salud que se basó, para el análisis de los datos, en las directrices nacionales de la Agenda de Compromisos del Niño. Los resultados evidenciaron la vulnerabilidad institucional del programa, proveniente de problemas relacionados a la estructura y proceso, con implicaciones en los resultados. Considerando la adecuación de los criterios adoptados por el programa para definición de los recién nacidos con riesgo y de las intervenciones y estrategias propuestas, que se muestran en consonancia con la Agenda de Compromisos, se apunta la necesidad de los administradores de priorizarlo, introduciéndolo efectivamente en la política pública de salud a ser desarrollada en el ámbito del municipio, para reversión de la vulnerabilidad institucional identificada.

Descriptores: Evaluación de Servicios de Salud; Grupos Vulnerables; Recién Nacido; Vulnerabilidad.

\section{Introduction}

Historically, Brazilian health policies have focused on the maternal-infant group. In this sense, the MaternalInfant Health Program was created, which evolved to the Comprehensive Care Delivery Program to Woman's and Child Health in the last decades of the 20th century. Specifically regarding the development of Brazilian childcare policies, with a view to organizing the main guidelines and overcoming the disarticulation among different care levels, in 2004, the Ministry of Health proposed the Agenda of Commitments to Children and Child Mortality Reduction, in which activities focus on care lines, which in general presupposed a global view on the dimensions of users' lives $^{(1)}$.

In view of the main child morbidity and mortality causes in Brazil, one of the priority care lines was At-Risk Newborn Monitoring, establishing Health Surveillance actions by the primary healthcare team, including early identification and care maintenance 
based on active search(1).

In the municipal context of this study, since 1997, the Secretary of Health has developed the Growing Happily Program, aiming for the identification of at-risk newborns, which should receive home visits (HV) during the first ten days of life, involving the multiprofessional team working at health units (HU). Then, the newborns receive priority monitoring. The first medical appointment should take place within one month of life and, from that point onwards, intercalated medical and nursing consultations every two weeks or, if necessary, every week.

To establish the neonatal risk, the program under analysis focuses on biological aspects: weight at birth below 2500g, gestational age at birth below 37 weeks, disease leading to hospitalization at intensive or intermediary care units during neonatal period, congenital malformation, fifth-minute Apgar below seven and being a child of a human immunodeficiency virus-positive mother. Social aspects are also taken into account: living in a risk area, maternal age below 18 years, unemployed family head or mother as family head, parents using drugs, illiterate mother, two or more dead children, no partner, less than four prenatal consultations or psychiatric problems jeopardizing childcare.

This study aimed to assess the structure, process and outcomes of at-risk newborn care delivery to infants enrolled in the Growing Happily Program during their first year of life. The intent is to help professionals to improve primary health care delivery and managers to elaborate public health policies for the child group.

\section{Method}

A population-based epidemiological health program assessment study was carried out. Donabedian's model(2) was used as a reference framework for the assessment and outcomes were discussed in view of the current guidelines determined in the national child healthcare policy, more specifically in the Agenda of Commitments to Children and Child Mortality Reduction ${ }^{(1)}$. The concept of program vulnerability was also used, which provides a practical and objective sense to verify the success and failure of health actions ${ }^{(3)}$.

Botucatu, where this study was accomplished, is considered a medium-sixed city, located in the central region of São Paulo State, Brazil, with a population of approximately 120,000 inhabitants. Its public primary healthcare network comprises three Polyclinics; five HU working in the traditional health center model and eight Family Health Units (FHU) with ten teams.

Two questionnaires were constructed for data collection: the nurses responsible for the HU answered the first, with variables related to program structure; one of the researchers completed the second questionnaire, about the process and outcomes of at-risk newborn care during the first year of life, based on existing records in the children's files at the HU. Before reaching the final form, these instruments went through adjustments, so as to comply with the study aims.

The indicators regarding the structure to put the Program in practice considered the number of units where: the newborns enrolled in the program were identified in the file; children in the program were registered in a specific book; HV cards were filed in the children's file; at-risk children were considered a priority for medical and nursing consultations; there was a copy of the Program; physicians and nurses participated in groups of pregnant women and newborns during the month before data collection. As for human resources, the studied indicators were based on the number of units where: care delivery to at-risk newborns was considered part of nurses and physicians' activities; nursing auxiliaries were trained for care delivery to atrisk newborns and physicians and nurses knew about the total number of children in the Program.

To study the care process, the proportions of children who received HV during the first ten days of life and who were monitored in childcare consultations in the primary healthcare network were analyzed as indicators, as well as the number of occasional attendances at $\mathrm{HU}$ during the first year of life and the proportion of children who were attended at the $\mathrm{HU}$ for all occasional attendances during the first year of life.

The proposed indicators to assess the program outcomes were: percentage of children who received all vaccines indicated for the first year of life: percentage of adverse health results (death or hospitalization) during the first year of life; percentage of children attended during medical or nursing consultations at the age of 12 months and percentage of children who received breast milk at the age of 12 months.

Research participants included all newborns living in Botucatu who were classified as at risk, born between March $3^{\text {rd }}$ and September $5^{\text {th }} 2006$, totaling 298 children, which corresponds to $52.9 \%$ of the 563 births that occurred in the city during this period. The period was chosen because it permitted the assessment 
of the Program's final version, put in practice at the start of 2006.

Independently of the place of birth or monitoring during the first year of life, it was considered that all newborns should receive HV and be vaccinated in the public health network. As part of the children was monitored at private childcare services, however, the total number of newborns considered for some variables was 185 .

One of the authors typed the database, whose consistency was tested based on associated questions. EpiInfo software version 3.4.3 was used for analysis, based on descriptive statistics, and indicators are presented through relative and absolute frequencies.

Approval for this study was obtained from the Institutional Review Board. Orientations for research involving human beings (Of. 598/2006-CEP) were complied with. After receiving further information about the research, the interviewed nurses were invited to participate and those who agreed signed the Informed Consent Term for Participation in Scientific Research. Exemption from the signing of this term was requested to the Institutional Review Board for the use of secondary data.

\section{Results}

In total, 298 children were studied, briefly characterized as follows. Most were born at a secondarylevel hospital $(52.0 \%)$, full-term $(77.0 \%)$ and through vaginal birth (61.0\%). At birth, $31.6 \%$ were low weight and $92.0 \%$ received an Apgar score of seven or more in the fifth minute of life. Half of the children were male, $2 \%$ displayed malformation and $4.4 \%$ had to be hospitalized at intensive or intermediary care units at birth. Regarding risk factors at birth, social factors were the most frequent (59.7\%), followed by the association between biological and social (22.8\%) and biological only $(17.5 \%)$. Most of the mothers were between 19 and 30 years old $(52.8 \%)$, had been approved in school for eight years or more $(62.3 \%)$, received support from the child's father (59.4\%) and had participated in seven or more prenatal consultations $(62.8 \%)$. The family head was unemployed in $10.7 \%$ of cases.

Structure data at the 16 Health Units evidence that, at most of these, children enrolled in the Program were not identified, but received priority care; $56.2 \%$ of the nurses and $12.5 \%$ of the physicians knew about the number of children enrolled in the Program (Table 1).
Table 1 - Structure of the Growing Happily Program at the Primary Health Care Unit $(n=16)$. Botucatu, Brazil, 2007

\begin{tabular}{|c|c|c|}
\hline Program Structure & No & $\%$ \\
\hline \multicolumn{3}{|l|}{ Identification of children in the program } \\
\hline Yes & 2 & 12.5 \\
\hline No & 14 & 87.5 \\
\hline \multicolumn{3}{|l|}{ File of visiting cards in patient file } \\
\hline Yes & 15 & 93.7 \\
\hline No & 1 & 6.3 \\
\hline \multicolumn{3}{|l|}{ Registration book at the unit } \\
\hline Yes & 11 & 68.7 \\
\hline No & 5 & 31.3 \\
\hline \multicolumn{3}{|c|}{ Priority of at-risk newborns for medical/nursing consultation } \\
\hline Yes & 13 & 81.3 \\
\hline No & 3 & 18.7 \\
\hline \multicolumn{3}{|l|}{ Copy of program at the unit } \\
\hline Yes & 4 & 25.0 \\
\hline No & 12 & 75.0 \\
\hline \multicolumn{3}{|c|}{ Participation of nurse in group of pregnant women } \\
\hline Yes & 7 & 43.7 \\
\hline No & 9 & 56.3 \\
\hline \multicolumn{3}{|c|}{ Participation of physician in group of pregnant women } \\
\hline Yes & 0 & 0.0 \\
\hline No & 15 & 93.8 \\
\hline Not informed & 1 & 6.2 \\
\hline \multicolumn{3}{|l|}{ Participation of nurse in group of newborns } \\
\hline Yes & 5 & 31.1 \\
\hline None & 11 & 68.9 \\
\hline \multicolumn{3}{|c|}{ Participation of physician in group of newborns } \\
\hline Yes & 0 & 0.0 \\
\hline No & 15 & 93.8 \\
\hline Not informed & 1 & 6.2 \\
\hline \multicolumn{3}{|c|}{ Care delivery to at-risk newborn by physician } \\
\hline Yes & 16 & 100.0 \\
\hline No & 0 & 0 \\
\hline \multicolumn{3}{|c|}{ Care delivery to at-risk newborn by clinical nurse } \\
\hline Yes & 15 & 93.8 \\
\hline No & 1 & 6.2 \\
\hline \multicolumn{3}{|l|}{ Nursing auxiliaries trained for the program } \\
\hline Yes & 10 & 62.5 \\
\hline No & 4 & 25.0 \\
\hline Does not know & 2 & 12.5 \\
\hline \multicolumn{3}{|c|}{ Nurse knows the number of at-risk newborns } \\
\hline Yes & 9 & 56.2 \\
\hline No & 7 & 43.8 \\
\hline \multicolumn{3}{|c|}{ Physician knows the number of at-risk newborns } \\
\hline Yes & 2 & 12.5 \\
\hline No & 14 & 87.5 \\
\hline
\end{tabular}

As for the care process, HV coverage was $54.0 \%$. For $68.5 \%$ of the children, vaccines were up-to-date and $2.7 \%$ received breast milk at the age of 12 months (Table 2).

Table 2 - Care process of the Growing Happily Program. Botucatu, Brazil, 2007

\begin{tabular}{|c|c|c|}
\hline Care Process & No & $\%$ \\
\hline \multicolumn{3}{|l|}{ Visits $(n=298)$} \\
\hline Yes & 161 & 54.0 \\
\hline No & 137 & 46.0 \\
\hline
\end{tabular}

(continue...) 
Table 2 - continuation

\begin{tabular}{|c|c|c|}
\hline Care Process & No & $\%$ \\
\hline \multicolumn{3}{|c|}{ Age (days) when receiving visit $(n=298)$} \\
\hline Up to 10 & 63 & 21.1 \\
\hline More than 10 & 98 & 32.9 \\
\hline Not visited & 137 & 46.0 \\
\hline \multicolumn{3}{|l|}{ Vaccination up to date $(n=298)$} \\
\hline Yes & 204 & 68.5 \\
\hline No & 36 & 12.1 \\
\hline Not informed & 58 & 19.4 \\
\hline \multicolumn{3}{|l|}{ Childcare at Health Unit $(n=298)$} \\
\hline Yes & 185 & 62.1 \\
\hline No & 113 & 37.9 \\
\hline \multicolumn{3}{|l|}{ Type of care at Health Unit $(n=185)$} \\
\hline Occasional & 53 & 28.6 \\
\hline Routine & 20 & 10.8 \\
\hline Occasional and routine & 112 & 60.6 \\
\hline \multicolumn{3}{|c|}{ Care delivery at the age of 12 months $(n=185)$} \\
\hline Yes & 18 & 9.7 \\
\hline No & 167 & 90.3 \\
\hline \multicolumn{3}{|c|}{ Breastfeeding at the age of 12 months $(n=185)$} \\
\hline Yes & 5 & 2.7 \\
\hline No & 180 & 97.3 \\
\hline \multicolumn{3}{|l|}{ Adverse results $(n=185)$} \\
\hline Yes & 22 & 11.9 \\
\hline No & 163 & 88.1 \\
\hline \multicolumn{3}{|l|}{ Type of adverse result $(n=22)$} \\
\hline Hospitalization & 14 & 63.6 \\
\hline Infant death & 8 & 36.4 \\
\hline
\end{tabular}

\section{Discussion}

All at-risk infants born during one semester of 2006 were studied. The collected data referred to the first year of life. The population representativeness is a highly positive aspect of this study. Some weak points should be highlighted though: to analyze the structure, the nurses responsible for the $\mathrm{HU}$, who were aware of the study objectives, served as the informants; to analyze the process, data were obtained from the children's files and, occasionally, health actions that were performed but not registered were not considered. Thus, the results of the structure analysis may contain some positive bias, while the process analysis results may contain a negative bias.

The incidence of at-risk newborns during the study period can be considered high: $52.9 \%$. It should be kept in mind that, according to the program, these children need to be visited until the tenth day of life and that, during the first year, they should receive a distinguished care routine. This clearly demonstrates the challenge posed to local health units.

A first aspect that needs to be observed relates to the pertinence of classification in the risk area the Growing Happily Program currently adopts. This classification was defined in 1995, based on a study about perinatal mortality carried out in the same city ${ }^{(4)}$.
The present study results revealed that $87.6 \%$ of at-risk newborns lived in those areas, a level that is definitely high. Living in a risk area corresponds to one of the axes of social risk, according to the Program. Other social risk axes include: mother younger than 18 years; illiterate mother; previous history of child death; unemployed family head or mother as family head; mother without partner/support; mother without prenatal follow-up (three consultations or less) and mother with psychiatric problem. Hence, more factors were included than in the Agenda of Commitments(1), which only includes adolescent mother, with low education level, history of child death and living in a risk area.

Probably due to this expansion, the frequency of children at social risk was high: $82.5 \%$, with $59.7 \%$ displaying exclusively social risk. The Program also considers biological risk factors, such as: birth weight of $2500 \mathrm{~g}$ or less; gestational age at birth below 37 weeks; disease justifying hospitalization at intensive or intermediary neonatal care units; fifth-minute Apgar score below seven; congenital malformation and HIVpositive mother. Among the children under analysis, $40.3 \%$ showed one or more of these factors. The biological criteria closely approximate those established in the Agenda of Commitments(1) and allow health services to develop specific strategic actions for adequate child healthcare delivery, with a view to minimizing damage. Only the last two risk factors mentioned are not covered in the Agenda of Commitments which, on the counterpart, proposes the inclusion of children whose mothers/caregivers needed special orientation upon discharge from the maternity/newborn care unit ${ }^{(1)}$.

Public health program and project assessment models should be accomplished in a crescendo, starting with the measurement of service provision indicators, that is, by the assessment of the program in terms of its foundations and technical adequacy for the epidemiological context and for the health system. Regarding technical and political criteria to define the child as at-risk, the Growing Happily Program is adequate. With respect to the interventions and strategies to put it in practice, the program also showed to be adequate, establishing health actions that can knowingly exert positive influence on child health, such as HV during the first ten days of life. Now, what was programmed should be confronted with what was offered to the target population, which is the second phase of the assessment model(5).

The Agenda of Commitments states that health professionals should not lose opportunities, at the health 
unit, at the newborn's home or in collective spaces, so as to benefit the child through comprehensive and multiprofessional care delivery ${ }^{(1)}$, which is even more relevant for at-risk newborns. According to the guidelines of the Growing Happily Program, at-risk children should be identified and registered in specific books at the reference units. Their forms should be included in their patient files, so that professionals can immediately recognize them when they visit health services. These study results appoint that these procedures are not constant practice in the city: some units do not have a registration book, the children are not identified at most of them and no copy of the Program is available. Hence, how can one not lose opportunities if the target population is unknown, and sometimes even the Program proposal?

Departing from the principle that the central issue health policies aiming for health equity should keep in mind is the reduction or elimination of differences deriving from factors that are considered avoidable and unfair(6), the priority at-risk newborns should receive is justified. Besides guaranteed access, increased problemsolving ability and care quality should be guaranteed(1). Regarding the priority given to care delivery to at-risk newborns, however, the data surveyed in this study reveal that problems may occur, due to the fact that these children are not identified in the service routine and due to the nurses and physicians' lack of knowledge about the number of children enrolled in the program.

Another process indicator adopted was: the development of educative activities in groups of pregnant women and newborns was unsatisfactory. Physicians and nurses' participation in this action was limited, revealing the maintenance of the traditional care model, in which care is offered almost exclusively based on individual medical consultations, not always enhancing welcoming of the anxieties, complaints and fears that are culturally associated with pregnancy and child care. On the opposite, the groups of pregnant women and newborns should constitute a space for sharing experiences, feelings and affection and for socializing technicalscientific and popular knowledge with participants ${ }^{(7)}$.

According to the Growing Happily Program, all professionals should participate in welcoming and care delivery to the newborns, although the strategies that should be used are not explicitly states. The same is true for the Agenda of Commitments, which appoints the need to overcome the disarticulation between different health system levels and the guarantee of comprehensive health care, with an agile and timely flow at each care level until the individual's complete recovery is achieved ${ }^{(1)}$.

In this study, the physician, and in most cases also the nurse, routinely attended all at-risk newborns. These professionals' limited participation indicates that this type of attendance has been mostly made feasible through individual consultations.

The Agenda of Commitments proposes the First Week of Comprehensive Health, directed at care delivery to mothers and newborns, recommending HV during the first week after birth ${ }^{(1)}$. In the analysis of the care process, HV coverage was generally low (54.0\%), and even lower when considering visits made until the tenth day of life (21.1\%). Based on HV as the most important process indicator, the Growing Happily Program's performance was quite unsatisfactory, reducing its potential for health surveillance and a positive impact on this group's health.

Home care in health is a device to review the health/ disease/care process concept and, therefore, capable of enhancing the incorporation of values leading to changes towards a care model committed to the establishment of a welcoming relation, marked by commitment and accountability for users' health ${ }^{(8)}$.

Besides the fact that the possibility of early HV to the newborn contributes to bring down mortality rates, other outcomes of this care form should be taken into account, such as the strengthening of bonding between health services and families, so as to facilitate health promotion actions at the family level(9), as well as the active search and early identification of at-risk children, as proposed in the Agenda of Commitments ${ }^{(1)}$.

The municipal public primary health care service's coverage in the periodical follow-up of at-risk newborns can be considered low (62\%). In view of the above characterization of mothers and newborns, as well as their residence areas, it seems quite improbable that the remaining $38 \%$ of children were being monitored in the private or convened health service system. Hence, part of the at-risk newborns at birth may be distanced from health surveillance, an action recommended in the program under assessment and in the Agenda of Commitments ${ }^{(1)}$.

When considering children who attend childcare consultations in the primary healthcare network, the fact that $28.6 \%$ did not receive routine care is remarkable, that is, each time these children were attended, there was a health problem that demanded the search for care at the $\mathrm{HU}$. This situation observed in the city is a source of concern, especially as these children should 
be under routine and frequent monitoring, including consultations to supervise their growth and development and vaccination status, among other fundamental child health promotion actions ${ }^{(1)}$.

In view of the low implementation level of recommended surveillance and newborn care actions and the low coverage, the possibility that the Program produced positive results regarding child health outcomes is small. Hence, it can be inferred that this condition is repeated, or gets even worse, for other children.

Negative indicators regarding the implementation process of the Program practically discredit the analysis of outcome or impact indicators ${ }^{(5)}$. Merely to describe the behavior of outcome indicators, vaccination coverage, breastfeeding indicators, hospitalizations and deaths were examined in the group of at-risk newborns followed in the Program.

At the end of the first year of life, vaccination was up-to-date for only $68.5 \%$ of the children. Vaccination in this age range is a priority in the federal and state context $^{(1,10)}$. For years, the basic operational target has been to vaccinate $100 \%$ of children younger than one year with all vaccines indicated for this age ${ }^{(11)}$. In the city under analysis, vaccination rooms are computerized, which should permit better monitoring of children's vaccination situation and active search actions for missing ones.

It is known that, when exclusively practiced until the age of six months and complemented with appropriate foods until the age of two years or more, breastfeeding shows great potential to transform growth and development and prevent illnesses in childhood and adult age. That is why the Agenda of Commitments proposes encouragement and orientations regarding maternal breastfeeding(1). Only $2.7 \%$ of the children received breastfeeding at the age of 12 months though, which is very low in comparison with the Brazilian situation. In $1989,37 \%$ of children were breastfed at the age of 12 months ${ }^{(12)}$ and, since then, the duration of breastfeeding has continuously increased in the country ${ }^{(13)}$.

The mother and the family, sociocultural and economic context influence the introduction of complementary feeding and breastfeeding. It is known, however, that health services' support can significantly contribute to improve the conduction of the child feeding process $^{(14)}$. These results appoint the need for new strategies to approach mothers.

The existence of the program could not avoid that 14 at-risk children attended at the HU were hospitalized during their first year of life, which may be related to the weaknesses indicated above. Besides, eight newborns died before completing one year. As six of them were extremely premature and were not discharged from hospital after birth, so that they were beyond the Program's reach, prenatal care qualification actions are suggested, in accordance with the Agenda of Commitments ${ }^{(1)}$. It should also be highlighted that two deaths were related to term children with fifth-minute Apgar scores of more than seven, characterizing avoidable deaths and, again, the fragility of the Program.

The fragility of at-risk newborn surveillance and care programs does not seem to be uncommon. Although rare, two papers were identified with similar program assessments. One of them, the newborn surveillance program in Londrina (PR), was assessed in terms of coverage and process. Like in the present research, participating nurses served as the informants. It was verified that $15.3 \%$ of at-risk children were not followed at primary health care units (better coverage than observed in Botucatu), 9.4\% attended convened or private services and the remainder was not found. Moreover, $60 \%$ of the units used standardized forms for the registration, identification and control of atrisk children ${ }^{(15)}$. The authors underlined deficiencies in the program, some of which were also observed in the Growing Happily Program, especially regarding the care process.

A second paper discusses the assessment of the previous version of Growing Happily, put in practice at a primary health care unit in Botucatu. Characteristics and indicators were similar to the present study, such as the predominance of children at social risk in comparison with biological risk, extremely low HV coverage, predominance of individual attendance and low vaccination coverage ${ }^{(16)}$.

\section{Conclusion}

On the whole, these study results evidence the institutional vulnerability of the assessed program's actions, due to structure and process-related problems, and affecting the program outcomes.

In terms of structure, the lack of a Program copy at the units is highlighted; the non-identification of atrisk children in the files: absence of group education activities for pregnant women and newborns and physicians and nurses' lack of knowledge about the total number of at-risk children at birth being followed at the health unit. The process analysis revealed low coverage of $\mathrm{HV}$, especially during the first ten days of 
life, a relatively small proportion of at-risk children at birth being followed in public child health services and a large number of occasional healthcare attendances for these children. As for the outcomes, as expected, a large number of children showed incomplete vaccination, did not followed the proposed care protocol for at-risk newborns and did not receive breast milk at the age of 12 month. Hospitalization and death rates were also high, despite the priority established for these children.

In summary, the criteria the Program adopts to define at-risk newborns are adequate and the proposed interventions and strategies are in line with the Agenda of Commitments. Thus, managers need to make it a priority by effectively including it in public health care policies to be developed in cities, in order to reverse the identified institutional vulnerability. The researchers hope that the dissemination of these results will help managers and health professionals to elaborate municipal child healthcare policies.

\section{References}

1. Ministério da Saúde (BR). Agenda de compromissos para a saúde integral da criança e redução da mortalidade infantil. Brasília (DF): Ministério da Saúde; 2005. 80 p.

2. Donabedian A. The quality of care - how come it be assessed? J Am Med Assoc. 1988;260(12):1743-8.

3. Ayres JRCM. Vulnerabilidade e avaliação de ações preventivas. São Paulo: Casa de Edição;1996.

4. Macharelli CA. Mortalidade perinatal em Botucatu - SP 1991/1992. [Dissertação]. Ribeirão Preto (SP): Faculdade de Medicina/USP; 1995.

5. Santos IS. Avaliação do impacto de programas nutricionais. Rev Nutrição. (PUCCAMP) 2009;22(1):141-50.

6. Viana ALd'Á, Fausto MCR, Lima LD. Política de saúde e equidade. São Paulo em Perspectiva. 2003;17(1):58-68.

7. Delfino MRR, Patrício ZM, Martins AS, Silvério MR. O processo de cuidar participante com um grupo de gestantes: repercussões na saúde integral individualcoletiva. Ciênc Saúde Colet. 2004;9(4):1057-66.

8. Pereira MJB, Mishima SM, Fortuna CM, Matumoto

S. A assistência domiciliar: conformando o modelo assistencial e compondo diferentes interesses/ necessidades do setor saúde. Rev. Latino-Am. Enfermagem. 2005;13(6):1001-10.

9. Leite $W C L$, Perico LAD. Vigilância à saúde do recém nascido na Divisão de Saúde Comunitária. Acta Paul Enferm. 1996;9:74-8.

10. Governo do Estado de São Paulo (SP). Norma técnica do programa de imunização. São Paulo (SP): Coordenadoria de Controle de Doenças. Centro de Vigilância Epidemiológica "Prof. Alexandre Vranjac"; 2008. 68 p.

11. Ministério da Saúde (BR). Manual de Procedimentos para vacinação. Brasília (DF): Ministério da Saúde; 2007. 111 p.

12. Venâncio SI, Monteiro CA. Tendência da prática da amamentação no Brasil nas décadas de 70 e 80 . Rev Bras Epidemiol. 1998;1:40-9.

13. Réa MF. Reflexões sobre a amamentação no Brasil: de como passamos a 10 meses de duração. Cad Saúde Pública. 2003;19(Suppl):S37-45.

14. Santos CS, Lima LS, Javorski M. Fatores que interferem na transição alimentar de crianças entre cinco e oito meses: investigação em Serviço de Puericultura do Recife, Brasil. Rev Bras Saúde Mater Infant. $2007 ; 7: 273-80$.

15. Rossetto EG, Pizzo LG. Avaliação do programa de vigilância do recém-nascido de Londrina-Paraná. Ciênc Cuid e Saúde. 2007;6(2):148-56.

16. Manoel CM, Carandina L, Giarola LC. Programa de vigilância ao recém-nascido de risco: ações desenvolvidas no Centro de Saúde Escola de Botucatu. Rev Paul Pediatr. 2006;24(3):227-32. 